\title{
THE EVALUATION OF THE BALKAN COUNTRIES RESULTS RELATIVE TO ESTABLISHING EFFECTIVE MARKET COMPETITION
}

\author{
Vladimir Radivojević \\ Regionalni centar Ministarstva odbrane Niš
}

Intense competition among market participants is the foundation of a successful national economy in a globalized world. This is the reason why almost every country in contemporary business environment strives to realize the highest possible level of effective market competition. The aim of the paper is to evaluate the results of the Balkan countries in the process of establishing effective market competition and determine the existence of a correlation between the effective market competition and global competitiveness of those countries. The study is conducted by empolying comparative and correlation analyses. The research findings indicate that the Balkan countries, Serbia particularly, have achieved modest results in terms of establishing effective market competition in the previous period and stress the need for improving the key factors in this field in the future. The study may be beneficial to competition policy makers of the Balkan countries, but also researchers in the field of competition policy and national competitiveness.

Key words: effective market competition, competitiveness, Serbia, the Balkan countries

\section{INTRODUCTION}

Free market competition represents one of the basic preconditions for achieving economic and social goals of a country. Thus, a significant task for every market economy is to create a favorable environment for the expression of individual preferences of the population and economic entities, and to harmonize them with the collective preferences at the same time. It means creating conditions for achieving goals of enterprises and consumers, which leads to economic efficiency, both at micro and macro level. In the process of realizing this task, it is necessary to determine a framework for the economic entity behavior and ensure stability in the expression of their interests and achieving goals.

Competition policy is an important segment of public policies that regulates behavior of market participants in order to reach the highest value of customer welfare, as well as to achieve the necessary level of economic efficiency and social welfare. Adequate regulation is a key precondition for successful competition policy. However, adopted legal solutions in the field of competition policy provide only a 
necessary institutional framework for the efficient functioning of markets and the establishment of effective competition among its participants. The effectiveness of this framework needs to be evaluated by market analysis based on empirical results achieved in creating an environment that encourages competition intensification.

Modest results of some Balkan countries relative to competition policy impose the need to increase institutional capacity, upgrade the regulations and their clarity in a manner that will ensure reaching an efficient market economy. The aim of this paper is to evaluate the results of Serbia and other Balkan countries in the process of establishing effective market competition, and determine the existence of a correlation between the effective market competition and global competitiveness of those countries. The goal is to identify the key competitiveness factors for improving effective market competition in the Balkan countries. This analysis and its results could give guidance to competition policy makers of the Balkan countries in defining development goals and improving critical factors of national competitiveness in this field.

The first part of the paper provides a theoretical background and literature review. Research methodology, the hypothesis, and database are given in the second section of the paper. The research results are presented and discussed in the third part. The last section summarizes the conclusions and recommendations for improving competition policy in Serbia and other Balkan countries.

\section{Theoretical background and literature review}

In dominant part of economic literature, competition is presented as a desirable state of every market economy and its intensity as a dynamic category that must be carefully supported by the state. Effective market competition has multiple positive effects on economic efficiency and overall social welfare. Contrary to this, noncompetitive market structures often result in setting up a company or strengthening the already dominant one, which can set prices above the competitive level, determine business conditions to achieve higher profits, oblige other participants in the supply chain, limit the existing competition, and prevent the entry of new competitors.

However, if non-competitive environment happens to be created, it need not and must not be sustainable in the long run. An adequate competition policy can eliminate the existing and potential market imperfections that threaten to distort competition. Nevertheless, evidence shows that the most complex problem in transitional economies, as it is the case with some Balkan countries, is the struggle against monopolies, which are mostly remainders of the command economy. Despite its negative impact on economic efficiency and social welfare, such market structures persist even today.

Competition policy and the analysis of competition intensity in various market structures are very challenging research areas to both theoreticians and practitioners. Consequently, there is a large body of economic studies dealing with different aspects of competition policy and market structures. The dominant part of studies about competition policy explore one or more aspects of market participants' behavior that could have potential negative effects on competition: 
(1) Restrictive agreements - tacit collusion between market participants about production quantity, sale prices, etc. (cartels);

(2) Abuse of dominant position - limiting production, increasing prices, and conditioning other market participants by the dominant undertaking;

(3) Merger control - an acquisition (merger) process between market participants that could have negative effects on competition.

The abovementioned aspects of the behavior of market participants are important part of contemporary textbooks of industrial economies (Ferguson \& Ferguson, 1994; Carlton \& Perloff, 1999; Motta, 2004; Lipczyinski, Wilson \& Goddard, 2009). Moreover, they are an integral part of almost every modern law on the protection of competition. Therefore, they are an indispensable research subject of competition policy in the European Union (Bishop \& Walker, 2002; Stojanović, 2003; Jones \& Sufrin, 2008; Cerovac, 2010; Blanco, 2011), the United States of America (Williamson, 1968; White, 1993; Lin et al., 2000; Gilbert, 2018), as well as in any other economic system such as Serbia (Begović \& Mijatović, 2002; Begović \& Pavić, 2010; Protić \& Lazarević, 2015; Radivojević, 2018).

Competition policy based on effective market competition eliminates the possibility of creating restrictive agreements, abuse of dominant position, and a merger between market participants that could have negative effects on competition. There are numerous empirical studies that examine the level of market competition in various industries worldwide. For example, Grzybowski (2008) and Whalley \& Curwen (2012) explore market competition in the mobile telecommunications industry in European countries. Bendinelli, Bettini \& Oliveira, (2016) and Oliveira \& Oliveira (2018) analyse the level of market concentration and competition intensity in the airline industry. There is also a large body of similar studies in the banking industry (Bikker \& Haaf, 2002; Michis, 2016), automobile industry (Levinsohn, 1994; Berry, Levinsohn \& Pakes, 1999; Tansey \& Raju, 2017), coal industry (Chen, 2013; Yang, Zhang \& Wang, 2017), etc.

\section{Research methodology, the hypothesis, and database}

As mentioned in the introduction section, the goal of this paper is to explore the results of the Balkan countries (with special emphasis on Serbia) in the process of establishing effective market competition and determine the existence of a correlation between the effective market competition and global competitiveness of these countries. In accordance with the aims of the research, the author tested the following hypothesis:

(H): There is a positive correlation between the effective market competition and the global competitiveness of the Balkan countries.

Information basis of this research consists of the secondary data published by the World Economic Forum (WEF) in the Global Competitiveness Report in the fiveyear period from 2013-2014 to 2017-2018. Global Competitiveness Report is the publication where WEF ranks countries according to their results in different fields 
(scores in the interval from 1 to 7 ) that are summarized in the Global Competitiveness Index (GCI).

The GCI is a composite index that combines 114 indicators which are grouped into 12 pillars. There are three key indicators within the Good market efficiency pillar of GCI (6th pillar) that point to the level of competition intensity and results of anti-monopoly policy in the observed countries:

(1) Intensity of local competition;

(2) Extent of market dominance;

(3) Effectiveness of anti-monopoly policy.

The results achieved by the Balkan countries in these three indicators represent the basis for analysis. In order to simplify the presentation of these indicators in the further text, the author will use the common name for all three indicators: indicators of effective market competition. It is important to note that there are a lot of papers that use these indicators (among others) in analysing the results of anti-monopoly policy in different countries (Leon, 2012; Lončar \& Milošević, 2013).

The following ten Balkan countries are included in the analysis: Albania, Bosnia and Herzegovina, Bulgaria, Croatia, Greece, Macedonia, Montenegro, Romania, Serbia, and Slovenia.

The research is carried out by empolying comparative and correlation analyses. Comparative analysis is used to present the results and relative position of each Balkan country in a comparative perspective (in the Balkan group of countries, but also in a global map). Correlation analysis is used to examine the interdependence between the average score of effective market competition indicators and GCI of the Balkan countries.

\section{Research results and discussion}

\subsection{Analysis of Serbian results in terms of establishing effective market competition}

According to WEF Reports published in the last five years (from 2013-2014 to 2017-2018), Serbia achieves modest results in the process of establishing effective market competition. Table 1 indicates the score of Serbia in Intensity of local competition, Extent of market dominance, and Effectiveness of anti-monopoly policy indicators (indicators of effective market competition) in the period from 2013-2014 to 2017-2018.

Table 1 shows that Serbia has improved the average score of effective market competition indicators in the observed five-year period. Its score is increased by 0.47 (from 3.13 in 2013-2014 to 3.60 in 2017-2018). Improvement was recorded in all the three indicators. Intensity of local competition is increased by 0.7 , extent of market dominance by 0.6 , and effectiveness of anti-monopoly policy by 0.1 . Regardless of the progress made in recent years, it is evident that Serbia belongs to the group of countries with poor performances with respect to effective market competition. This is clearly indicated by the fact that the average score in the observed period ranged 
from 3.13 to 3.60 , which is approximately half of the maximum score that can be achieved (7.00).

Table 1: The score of Serbia in the indicators of effective market competition (from 2013-2014 to 2017-2018)

\begin{tabular}{|c|c|c|c|c|c|}
\hline \multirow[b]{2}{*}{ Year } & \multicolumn{3}{|c|}{ Indicators of effective market competition } & \multirow[b]{2}{*}{$\begin{array}{l}\text { Average } \\
\text { score } \\
(2+3+4 / 3)\end{array}$} & \multirow{2}{*}{$\begin{array}{l}\text { Changes of } \\
\text { average score } \\
\text { (from the } \\
\text { previous year) }\end{array}$} \\
\hline & $\begin{array}{c}\text { Intensity of } \\
\text { local } \\
\text { competition }\end{array}$ & $\begin{array}{c}\text { Extent of } \\
\text { market } \\
\text { dominance }\end{array}$ & $\begin{array}{c}\text { Effectiveness of } \\
\text { anti-monopoly } \\
\text { policy }\end{array}$ & & \\
\hline 1 & 2 & 3 & 4 & 5 & 6 \\
\hline $2013-2014$ & 3.8 & 2.6 & 3.0 & 3.13 & - \\
\hline $2014-2015$ & 4.2 & 2.8 & 3.3 & 3.43 & +0.30 \\
\hline $2015-2016$ & 4.3 & 2.7 & 3.1 & 3.37 & -0.06 \\
\hline $2016-2017$ & 4.2 & 2.9 & 3.0 & 3.37 & - \\
\hline $2017-2018$ & 4.5 & 3.2 & 3.1 & 3.60 & +0.23 \\
\hline Total change* & +0.7 & +0.6 & +0.1 & +0.47 & +0.47 \\
\hline
\end{tabular}

* Note: The results obtained by comparison of score in 2013-2014 with the score in 2017-2018

Source: World Economic Forum, The Global Competitiveness Report, 2013-2014, 2014-2015, 2015-2016, 2016-2017, 2017-2018

For the purpose of analysing the results of effective market competition indicators and its correlation with the results in global competitiveness of Serbia more precisely, it is necessary to present the score and rank of Serbia in the global map. It provides an insight into the correlation between the effective market competition indicators and global competitiveness indicators of Serbia. Table 2 presents the score and rank of Serbia in GCI in the period from 2013-2014 to 20172018.

Table 2: The score and rank of Serbia in GCI (from 2013-2014 to 2017-2018)

\begin{tabular}{|c|c|c|c|c|c|}
\hline \multirow{2}{*}{ Year } & \multirow{2}{*}{$\begin{array}{c}\text { Number of } \\
\text { surveyed } \\
\text { countries }\end{array}$} & \multicolumn{2}{|c|}{ GCI } & \multicolumn{2}{c|}{ Changes in GCI } \\
\cline { 3 - 6 } & Score & Rank & Score & Rank \\
\hline $2013-2014$ & 148 & 3.77 & 101 & - & - \\
\hline $2014-2015$ & 144 & 3.90 & 94 & +0.13 & +7 \\
\hline $2015-2016$ & 140 & 3.89 & 94 & +0.01 & - \\
\hline $2016-2017$ & 138 & 3.97 & 90 & +0.08 & +4 \\
\hline $2017-2018$ & 137 & 4.14 & 78 & +0.17 & +12 \\
\hline Total change* & - & - & - & +0.39 & +23 \\
\hline
\end{tabular}

* Note: The results obtained by comparison of score and rank in 2013-2014 with those in 2017-2018 Source: World Economic Forum, The Global Competitiveness Report, 2013-2014, 2014-2015, 2015-2016, 2016-2017, 2017-2018

Data presented in Table 2 show continuous improvement of Serbian global competitiveness in the period from 2013-2014 to 2017-2018. Serbia increased its national competitiveness score by 0.39 and its global rank by 23 places in the observed period. An overall interpretation of these results indicates that they correspond with the results achieved in the indicators of effective competition. A 
more detailed comparison of the indicators of effective market competition score (Table 1) and the score of GCI (Table 2) is graphically illustrated in Figure 1.

Figure 1: The comparison of Serbian score in the effective market competition indicators and GCI (from 2013-2014 to 2017-2018)

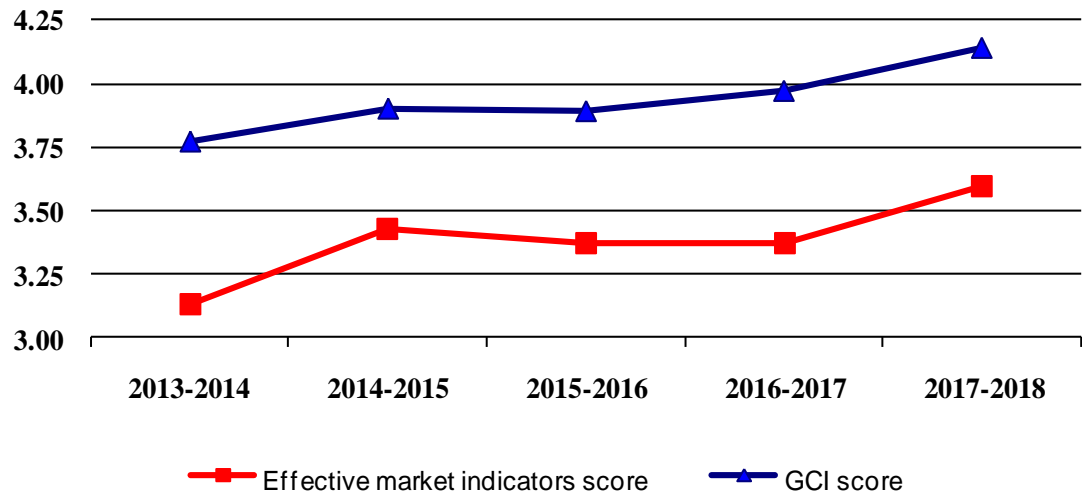

Figure 1 illustrates the correlation between the score of indicators of effective market competition and global competitiveness of Serbia in the period from 20132014 to 2017-2018. Firstly, a score increase of indicators of effective market competition by 0.30 is followed by a score increase of GCI by 0.13 in 2014-2015. After that, a minor score decrease of indicators of effective market competition by 0.06 places in 2015-2016 is followed by a minor increase of GCI by 0.01 . The next year's score of Serbia in terms of indicators of effective market competition did not change, while the score of GCI slightly increased by 0.08 . Finally, a score increase of indicators of effective market competition by 0.23 in 2017-2018 is followed by a score increase of GCI by 0.17 in the same year. The abovementioned score changes in both competitiveness categories in the five-year period indicate the existence of a correlation between them.

An important finding of the previous analysis is that the level of effective market competition development of Serbia is quite lower than the level of its global competitiveness. However, there is a slight trend of convergence of these categories in the observed period. The score of effective market competition is increased by 0.47 (from 3.13 in 2013-2014 to 3.60 in 2017-2018), while the score of GCI is increased by 0.39 (from 3.77 in 2013-2014 to 4.14 in 2017-2018).

\subsection{The analysis of the Balkan countries results relative to establishing effective market competition}

In order to analyse the achievements of the Balkan countries in the process of establishing effective market competition, the scores and global ranks (2017-2018) of all the Balkan countries in terms of effective market competition are presented in Table 3. The data serve to understand the relative position of each Balkan country in a comparative perspective. 
Table 3: The score and global rank of the Balkan countries in the effective market competition indicators (2017-2018)

\begin{tabular}{|c|c|c|c|c|c|c|c|c|}
\hline \multirow[t]{2}{*}{ Country } & \multicolumn{2}{|c|}{$\begin{array}{l}\text { Intensity of } \\
\text { local } \\
\text { competition }\end{array}$} & \multicolumn{2}{|c|}{$\begin{array}{l}\text { Extent of market } \\
\text { dominance }\end{array}$} & \multicolumn{2}{|c|}{$\begin{array}{l}\text { Effectiveness of } \\
\text { anti-monopoly } \\
\text { policy }\end{array}$} & \multirow{2}{*}{$\begin{array}{l}\text { Average } \\
\text { score of all } \\
\text { indicators } \\
(2+4+6 / 3)\end{array}$} & \multirow{2}{*}{$\begin{array}{l}\text { Rank on the } \\
\text { list of isolated } \\
\text { group of } \\
\text { Balkan } \\
\text { countries }\end{array}$} \\
\hline & Score & $\begin{array}{c}\text { Global } \\
\text { rank }\end{array}$ & Score & $\begin{array}{c}\text { Global } \\
\text { rank }\end{array}$ & Score & $\begin{array}{c}\text { Global } \\
\text { rank }\end{array}$ & & \\
\hline 1 & 2 & 3 & 4 & 5 & 6 & 7 & 8 & 9 \\
\hline Slovenia & 5.4 & 38 & 4.3 & 26 & 3.8 & 60 & 4.50 & 1 \\
\hline Macedonia* & 5.4 & 41 & 3.7 & 67 & 3.9 & 49 & 4.33 & 2 \\
\hline Greece & 5.1 & 71 & 3.9 & 58 & 3.5 & 81 & 4.17 & 3 \\
\hline Bulgaria & 4.8 & 91 & 3.8 & 61 & 3.5 & 85 & 4.03 & 4 \\
\hline Romania & 4.9 & 86 & 3.6 & 76 & 3.4 & 95 & 3.97 & 5 \\
\hline Montenegro & 4.4 & 122 & 3.5 & 84 & 3.6 & 75 & 3.83 & 6 \\
\hline Croatia & 4.7 & 102 & 3.1 & 113 & 3.4 & 91 & 3.73 & 7 \\
\hline Albania & 4.7 & 100 & 3.1 & 115 & 3.3 & 102 & 3.70 & $8 / 9$ \\
\hline $\begin{array}{l}\text { Bosnia and } \\
\text { Herzegovina }\end{array}$ & 4.5 & 117 & 3.2 & 107 & 3.4 & 88 & 3.70 & $8 / 9$ \\
\hline Serbia & 4.5 & 115 & 3.2 & 115 & 3.1 & 114 & 3.60 & 10 \\
\hline Average & 4.84 & - & 3.54 & - & 3.49 & - & 3.96 & - \\
\hline
\end{tabular}

*Note: Data for Macedonia (excluded in WEF 2017-2018) are from WEF 2016-2017

Source: World Economic Forum, The Global Competitiveness Report, 2016-2017, 2017-2018

The best positioned Balkan country according to the score and rank of effective market competition indicator is Slovenia (Table 3). It records the highest average score of 4.50, followed by second-ranked Macedonia (4.33), and third-ranked Greece (4.17). The first three Balkan countries are followed by Bulgaria, Romania, Montenegro, Croatia, Albania and Bosnia and Herzegovina (which share the $8^{\text {th }}$ and $9^{\text {th }}$ place in the Balkan group), and Serbia.

The data presented in Table 3 indicate poor performances of the majority of the Balkan countries in the process of establishing effective market competition. Furthermore, all Balkan countries except for Slovenia and Macedonia are positioned in the second half of the global list (from the $68^{\text {th }}$ to $137^{\text {th }}$ position) in at least one indicator of effective market competition. Greece and Bulgaria are positioned in the second half of the global list in two indicators (Intensity of local competition and Effectiveness of anti-monopoly policy), while all other Balkan countries (apart from Slovenia and Macedonia) record very low results in all three indicators of effective market competition.

Table 3 shows that Serbia is the worst positioned Balkan country in 2017-2018 according to the average score of the effective market competition indicators (3.60). Serbian score in all three effective market competition indicators is below the average score in those indicators of other Balkan countries. What is more, the global rank of Serbia in all three effective market competition indicators classifies it under the group of 24 countries in the world with the worst results in the process of establishing effective market competition. Serbia is ranked even at the $115^{\text {th }}$ position (out of 137 countries) in the world in terms of Intensity of local competition and 
Extent of market dominance, and also at the $114^{\text {th }}$ position in the world in terms of Effectiveness of anti-monopoly policy.

With the aim to examine the impact of the results achieved by the Balkan countries in the field of effective market competition upon their global competitiveness, it is necessary to compare the average score of the effective market competition indicators and the score of GCI. The data for analysis are presented in Table 4.

Table 4: The score of the Balkan countries in the effective market competition indicators and GCI (2017-2018)

\begin{tabular}{|l|c|c|}
\hline \multicolumn{1}{|c|}{ Country } & $\begin{array}{c}\text { Average score of } \\
\text { effective market } \\
\text { competition indicators }\end{array}$ & GCI \\
\hline Slovenia & 4.50 & 4.48 \\
\hline Macedonia* & 4.33 & 4.23 \\
\hline Greece & 4.17 & 4.02 \\
\hline Bulgaria & 4.03 & 4.46 \\
\hline Romania & 3.97 & 4.28 \\
\hline Montenegro & 3.83 & 4.15 \\
\hline Croatia & 3.73 & 4.19 \\
\hline Albania & 3.70 & 4.18 \\
\hline $\begin{array}{l}\text { Bosnia and } \\
\text { Herzegovina }\end{array}$ & 3.70 & 3.87 \\
\hline Serbia & 3.60 & 4.14 \\
\hline
\end{tabular}

*Note: Data for Macedonia (excluded in WEF 2017-2018) are from WEF 2016-2017

Source: World Economic Forum, The Global Competitiveness Report, 2016-2017, 2017-2018

Data from Table 4 suggest that the majority of Balkan countries achieve better scores in GCI than in the average score of effective market competition indicators. Only Slovenia, Macedonia, and Greece deviate from that proportion because these countries realize a better score in the effective market competition indicators. All other Balkan countries (Bulgaria, Romania, Montenegro, Croatia, Albania, Bosnia and Herzegovina, and Serbia) have poorer performances in the effective market competition indicators compared to GCI.

In order to examine the correlation between the average score of effective market competition indicators and GCI of the Balkan countries, the method of Pearson's correlation analysis is applied (see Table 5).

Table 5: Pearson's correlation coefficient between scores of the Balkan countries in the effective market competition indicators and GCI (2017-2018)

\begin{tabular}{|c|l|r|r|}
\hline \multicolumn{2}{|c|}{} & \multicolumn{1}{|c|}{ GCI } & \multicolumn{1}{c|}{ Competition } \\
\hline \multirow{4}{*}{ GCI } & Pearson's Correlation & 1 & $0.536(* *)$ \\
\cline { 2 - 4 } & Sig. (2-tailed) & 10 & .111 \\
\cline { 2 - 4 } & $\mathrm{N}$ & $0.536(* *)$ & 10 \\
\hline \multirow{3}{*}{ Competition } & Pearson's Correlation & .111 & 1 \\
\cline { 2 - 4 } & Sig. (2-tailed) & 10 & 10 \\
\cline { 2 - 4 } & $\mathrm{N}$ & \multicolumn{2}{|c}{} \\
\hline ** Correlation is significant at the 0.05 level (2-tailed)
\end{tabular}

Source: Author's calculation (SPSS 22) 
The value of Pearson's correlation coefficient of 0.536 presented in Table 5 indicates a moderate positive correlation between the average score of effective market competition indicators and GCI of the Balkan countries. However, the result of correlation analysis is not statistically significant (Sig. 2-tailed $>0.05$ ).

\section{CONCLUSION}

Research findings of the conducted empirical analysis suggest a few conclusions. First, it is shown that the majority of the Balkan countries are positioned in the second half of the global list according to the indicators of effective market competition. Moreover, all the Balkan countries except for Slovenia and Macedonia are positioned in the second half of the global list (from the $68^{\text {th }}$ to $137^{\text {th }}$ position) in at least one indicator of effective market competition in 2017-2018. Second, the results of comparative analysis indicate that Serbia is the worst positioned Balkan country in terms of establishing effective market competition. Serbian score in all three effective market competition indicators is below the average score of the Balkan countries in those indicators. Furthermore, the global rank of Serbia in all three effective market competition indicators (the $114^{\text {th }}$ and $115^{\text {th }}$ position out of 137 countries) classifies it under the group of 24 countries in the world with the worst results in the process of establishing effective market competition in 2017-2018. Finally, the results of correlation analysis indicate a moderate positive correlation between the average score of effective market competition indicators and GCI of the Balkan countries (the value of Pearson's correlation coefficient is 0.536). However, since the results are not statistically significant (Sig. 2-tailed $>0.05$ ), the hypothesis cannot be confirmed.

The general conclusion of this paper is that almost all Balkan countries and Serbia in particular have very poor performances in terms of effective market competition. All of them must put in a lot of efforts to make improvements that bring them closer to the first half of the global list. In the process of achieving that goal, they must improve all of three effective market competition indicators: Intensity of local competition, Extent of market dominance, and Effectiveness of anti-monopoly policy. The limitations of this study arise from the weakness of the GCI methodology. Nevertheless, the research findings of the study provide a solid starting point for a more detailed analysis of effective market competition performances of the Balkan countries.

\section{Reference}

Begović, B., \& Mijatović, B. (2002). Antimonopolska politika u SR Jugoslaviji. Beograd: Centar za liberalno-demokratske studije.

Begović, B., \& Pavić, V. (2010). Šta je to konkurencija i kako se štiti?. Beograd: Centar za liberalno-demokratske studije.

Bendinelli, W.E., Bettini, H.F., \& Oliveira, A.V., (2016). Airline delays, congestion internalization and non-price spillover effects of low cost carrier entry. Transport, 85, 3952. doi: doi.org/10.1016/j.tra.2016.01.001 
Berry, S., Levinsohn, J., \& Pakes, A. (1999). Voluntary export restraints on automobiles: Evaluating a trade policy. The American Economic Review, 89(3), 400-430.

Bikker, J., \& Haaf, K. (2002). Measures of Competition and Concentration in Banking Industry: A Review of Literature. Economic and Financial Modelling, 9, 53-98.

Bishop, S., \& Walker, M. (2002). The Economics of EC Competition Law. London: Sweet \& Maxwell.

Blanco, L. (2011). Market Power in EU Antitrust Law. Oxford: Hart Publishing Ltd.

Carlton, D., \& Perloff, J. (1999). Modern Industrial Organization. Massachusetts: AddisonWesley.

Cerovac, M. (2010). Pravo tržišnog natjecanja u Evropskoj uniji. In: Hodak Lj. (Eds.), Europska unija (pp. 247-283). Zagreb: Mate.

Chen, X.Y. (2013). Empirical Research on Chinese Coal Industry Concentration. Nanjing: Nanjing University of Aeronautics and Astronautics.

Ferguson, P., \& Ferguson, G. (1994). Industrial economics: Issues and perspectives. London: Macmillan.

Gilbert, S. (2018). Multi-Market Antitrust Economics. Quantitative Perspectives on Behavioral Economics and Finance. Cham: Palgrave Macmillan.

Grzybowski, L. (2008). The competitiveness of mobile telephony across the European Union. International Journal of the Economics of Business, 15, 99-115.

Jones, A., \& Sufrin, B. (2008). EC Competition Law. Oxford: Oxford University Press.

Leon, I. (2012). What are the relevant features for assessing economic competition in developing countries? SSRN Working paper. Retrieved from: http://ssrn.com/abstract=2169905 (27 January 2018).

Levinsohn, J. (1994). International trade and the U.S. automobile industry: Current research, issues, and questions. Japan and the World Economy, 6(4), 335-357.

Lin, P., Raj, B., Sandfort, M., \& Slottje, D. (2000). The US Antitrust System and Recent Trends in Antitrust Enforcement. Journal of Economic Surveys, 14(3), 255-306.

Lipczyinski, J., Wilson, J., \& Goddard, J. (2009). Industrial Organization: Competiton, Strategy, Policy. Third Edition. Harlow: Prentice Hall.

Lončar, D., \& Milošević, S. (2013). Characteristics of anti-monopoly policy and the effects of its application in Serbia. Ekonomika preduzeća, 1-2, 115-128.

Michis, A.A. (2016). Market concentration and nonlinear pricing in European banking. Journal of Economics and Business, 85, 1-12. doi: dx.doi.org/10.1016/j.jeconbus.2016.02.003

Motta, M. (2004). Competition Policy: Theory and Practice. Cambridge: Cambridge University Press.

Oliveira, M., \& Oliveira, A. (2018). What drives effective competition in the airline industry? An empirical model of city-pair market concentration. Transport Policy, 63, 165-175. doi: doi.org/10.1016/j.tranpol.2017.12.021

Protić, D., \& Lazarević, N. (2015). Politika konkurencije u Srbiji: U čemu je problem?. Beograd: Centar za evropske politike.

Radivojević, V. (2018). Uloga politike zaštite konkurencije u upravljanju determinantama konkurentske prednosti preduzeća. Niš: Društvo ekonomista Ekonomika Niš.

Stojanović, B. (2003). Tržište Evropske unije: Konkurencija i trgovinska politika. Niš: Ekonomski fakultet. 
Tansey, M., \& Raju, S. (2017). Pricing, concentration \& public policy: The U.S. automobile market. Journal of Policy Modeling, 39, 762-774. doi: dx.doi.org/10.1016/j.jpolmod.2017.07.004

Whalley, J., \& Curwen, P. (2012). Incumbency and market share within European mobile telecommunications networks. Telecommunications Policy, 36(3), 222-236.

White, L. (1993). Competition policy in the United States: An overview, Oxford review of economic policy, 9(2), 133-153. doi: doi.org/10.1093/oxrep/9.2.133

Williamson, O. (1968). Economies as an Antitrust Defense: The Welfare Tradeoffs. The American Economic Review, 58(1), 18-36.

World Economic Forum (2013-2014, 2014-2015, 2015-2016, 2016-2017, 2017-2018). The Global Competitiveness Report. Geneva: World Economic Forum. Retrieved from: https://www.weforum.org/reports (25 January 2018).

Yang, Q., Zhang, L., \& Wang, X. (2017). Dynamic analysis on market structure of China's coal industry. Energy Policy, 106, 498-504.

Primljeno 14. februara 2018, nakon revizije,

prihvaćeno za publikovanje 24. avgusta 2018.

Elektronska verzija objavljena 22. oktobra 2018.

Vladimir Radivojević je naučni saradnik zaposlen u Ministarstvu odbrane. Doktorirao je 2014. godine na Ekonomskom fakultetu Univerziteta u Nišu. Autor je jedne monografije i više od 30 naučnih radova u domaćim i međunarodnim naučnim časopisima. Član je uređivačkog odbora naučnog časopisa „Ekonomika“ i izdavačkog saveta naučnog časopisa „Economics of Sustainable Development“.

\section{EVALUACIJA REZULTATA BALKANSKIH ZEMALJA U POGLEDU USPOSTAVLJANJA EFEKTIVNE TRŽIŠNE KONKURENCIJE}

Intenzivna konkurencija među učesnicima na tržištu predstavlja osnovu uspešne nacionalne ekonomije u globalizovanom svetu. To je razlog zbog kog skoro svaka zemlja u savremenom poslovnom okruženju nastoji da realizuje najveći mogući nivo efektivne tržišne konkurencije. Cilj rada je da evaluira rezultate balkanskih zemalja u procesu uspostavljanja efektivne tržišne konkurencije i da utvrdi postojanje korelacije između efektivne tržišne konkurencije i nacionalne konkurentnosti ovih zemalja. Studija je sprovedena primenom komparativne i korelacione analize. Rezultati istraživanja ukazuju na skromne rezultate zemalja Balkana, a posebno Srbije, u pogledu uspostavljanja efektivne tržišne konkurencije u prethodnom periodu i naglašavaju potrebu za poboljšanjem ključnih faktora $u$ ovoj oblasti $u$ budućnosti. Studija je korisna donosiocima odluka u oblasti politike zaštite konkurencije balkanskih zemalja, ali i istraživačima u oblasti politike zaštite konkurencije i nacionalne konkurentnosti.

Ključne reči: efektivna tržišna konkurencija, konkurentnost, Srbija, zemlje Balkana. 